\title{
Morphosemantic Attributes of Meetei Proverbs
}

\author{
Lourembam Surjit Singh \\ Centre for Advanced Studies in Linguistics \\ Faculty of Arts Extension Building \\ University of Delhi, Delhi-110007, India \\ Department of Applied Science and Humanities \\ IILM-Academy of Higher Learning \\ Knowledge Park-II, Greater Noida-201306, U.P., India \\ E-mail: 1surjit24@yahoo.com
}

Doi:10.7575/aiac.alls.v.6n.3p.144

URL: http://dx.doi.org/10.7575/aiac.alls.v.6n.3p.144
Received: 06/02/2014

Accepted: 14/04/2015

\begin{abstract}
This study proposes to investigate the functions of morphosemantic in Meetei proverbs, particularly the attribution of different meanings of the lexical items in Meetei Proverbial verbs. Meetei society has been using proverbs in the all ages, stages of development, social changes, and cultural diversifications to mark their wisdom of social expertise. Meetei used proverbs as an important aspect of verbal discourses within the socio-cultural and ethno-civilization contexts in which skills, knowledge, ideas, emotion, and experiences are communicating. The language used in proverbs reflects the Meetei's status of life, food habits, belief systems, philosophy, cultural and social orientations. At the same time, various meanings attribute in Meetei proverbs in the forms of figurative, witty, pithy, didactic etc. The construction of these forms are grammatically insightful thereby creating spaces for a whole range of possibilities for investigating the features, functions and structure of verbal inflectional markers occurred in Meetei proverbial sentences.
\end{abstract}

Keywords: Proverbs, morphosemantics, features of lexical items, attributes of meanings and language

\section{Introduction}

A proverb is a terse didactic statement that is current in tradition or as an epigram says "the wisdom of many and the wit of one". It ordinarily suggests a course of action or passes a judgment on a situation (Maria Leach, 1984). This short sentence drawn from a long experience of the wisdom of life is an important aspect of verbal discourse, which various meanings are attributing in the society. Attribution of meaning reflects the people's status of life, belief systems, philosophy, cultural and social orientations. The languages of proverbs are commonly grammatically insightful, figurative, pithy, witty, well constructive, didactic and condensing wisdom of experience. Proverbs are generally well constructed strings of lexical items and affixes that exist in the language, and hence constituting higher grammatical units than phrases, clauses and sentences (Mensah, 2010). Abrahams (1972:119) also says that proverbs always stated in the form of a single sentence. Generally, there are certain remarks in proverbs, simply because they are witty, sententious, and used to embody wisdom. Thus, the use of proverbs in a particular language remains a veritable tool for the transmission of traditional values, beliefs, thoughts, emotions, philosophy, education and information.

Specifically in Linguistics, linguists investigate proverbs with the scope of hetero-situativity, poly-morphocity, polyfunctionality and poly-semanticity in simple form. It is of great significance that scholars pay their attention to the study in morphosyntactic, paradigmatic, syntagmatic, logical, structural and semantic aspects of these traditional utterances as communicative and strategic signs. Goodwin and Wenzel (1979) propose that structural analysis of texts will certainly gain value if semiotic aspects of proverbs as linguistic and cultural signs added to them with a special focus on actual proverb performance in speech acts. In this regards, David Cram (1983) and other linguists argue that the proverbs should be viewed as a lexical element with a quotational status. The sense of this lexical element is that a syntactic string of words that is learned and reused as a single unit with fixed internal and external structures. The reason of being in the quotational status is that generally the proverbs are typically invoked or cited rather than straight forwardly asserting in a sentence or daily conversations. For instance, proverbs are often quoted with such introductory formulas as "it seems to", "the proverbs says", "its saying as", "it is true that", my grandfather used to say, "everybody knows that", "the proverb says", etc. However, Cram's claim is not always true, it may have somewhat unreasonable in the thematic meaning of an actual conversational context of proverbial meaning. Because, we emphasize to that contributed meaning of which lexical items have shared with the actual contexts. Hence, proverbs may also be used without quotational formula.

In the grammatical description of Meetei proverbs, Meetei Proverbial Phrases and Meetei Riddles based on the literature of Manipuri in the context of morphosemantics are hardly found in Linguistics world. Most of the scholars used its nuances simply in literatures or folkloristic study, instead using linguistics tools in descriptive analysis. Beerjita 
Devi's (2007) proposes proverbs in the aspects of folkloristic motifs, socially attributive meanings, types, and it roles in Manipuri society, education, philosophy and literatures. In the other study, Mandakini Baruah (2008) investigates proverbs on the folkloristic motifs in the case of co-wife and stepmother in context of Assamese societal taboos. In their study, they only criticized proverbs and its features within the framework of folkloristic literature and they had contextualized the work neither in morphology nor in semantics. Though Devi and Baruah studied proverbs with various aspects in literature, we hardly found any study in aspects of linguistics. Hence, this study tries to investigate degrees of meanings that occurred in different morphs, allomorphs, morphemes and their features with reference to Meetei proverbs sentences within the framework of morphosemantics.

This work is organised as in the following: Section-1 draws the brief introduction along with few literature reviews. In theory and methods (Section -2), we study how the different aspects of morphosemantic features occur in various proverbial sentences. In the analysis of proverbs in Meeteilon (Section-3), we investigate different aspects of the attribution of meanings in Meetei proverbs based on which different lexical features occur in different morphemes. In conclusion (Section-4), some results have been drawn in the conclusion based on the investigations.

\section{Theory and Methods}

In language and literatures, various schools develop various theories categorizing different types of the nature of meaning. However, for proverbial phrases and sentences, we hardly found single theory that can be considered as universal theory in the study of meaning, particularly in linguistics. When we trigger to the semantics and pragmatics properties in proverbial meaning, the essence of the theories of meanings become one of the core framework in which meanings can be attributed and inferred in that properties. The theories like Referential Theory, the Ideational Theory, the Stimulus Theory, the Realist Theory, and the Contextual Theory are common for the studies of word and sentence meanings. Moreover, a meaning cannot interpret in one fixed dimension; it may be bound to various meanings and interpretations for various situations. Leech (1974) proposes seven types of meaning in order to represent the nature of elusive meaning such as Emotional/Connotative, Reflective, Affective, Conceptual/Denotative, Collocative, Stylistic and Thematic.

As Goddard (1998) says about language, proverbial language is also one of the most important and sophisticated instruments by which information, emotions, values, belief systems and other societal \& cultural practises are communicated. Every language has its own specific meanings based on their cultural and societal aspects. It is a big challenge to investigate all the grammatical features of meaning in a language, though, tries to investigate through some semantical and pragmatical frameworks in order to study meanings in all possible ways.

However, without particular morphological correlation, focusing on semantics or pragmatics alone would effectively reduce idiosyncratic interpretations of the lexical items, and without semantics and pragmatic correlations, extracting only the morphological functions or correlation of the lexical items would also be missing the pervasive semantic generalizations across the language. It demands for a study of morphosemantic based framework. Traditionally, in morphosemantics we study about the correlation between marker and meaning. The other approaches like constructional grammar (Croft, 2001) and semiotics (De Saussure, 1968) argue that the relationship between image acoustique and concept is symbolic. In collocational texts, marker may have different meanings and it functions as polysemy. Such markers can convey different meanings in different lexemes paradigmatically and syntagmatically. These may be the reasons why markers and meanings are sometimes non-isomorphism, in terms of polysemy and polymorphy. For this reason, only after studying symmetrically of both morphology and semantic would lead to a systematic interpretation in Meetei proverbs. It would also contextually emerge between certain conceptualizations in lexical semantics and certain morphological properties. For instance, in Efik Proverbs, according to Mensah (2010) the features of proverbs are identifying with the stylistic features that are commonly associated with Efik proverbs, and which gives its distinctiveness that are usually expressing in short, succinct and clear language, whose meanings may be transparent or opaque. Generally, while teaching to the children the processes of learning societal values of Efik have practiced through their proverbs. Mensa (2010) identically discussed that Efik proverbs have a rich system of inflection as exemplified by the inflectional capabilities of concord affixes in signaling the various verbal categories in relation with the root verb.

In case of some Tibeto-Burman Languages, constituents are highly agglutinative by nature. They have a structure of long polymorphic words constructions in which each morpheme corresponds to a single lexical meaning or grammatical function. A polymorph or a polymorpheme may consists one root or number of affixes indicating concord of person, negation, tense, etc. (Spenser, 1991). The Tibeto-Burman language like Meeteilon (Manipuri) also does have a long polymorphic feature and morphologically the construction of some Meetei proverbs have found highly agglutinative by nature. Therefore, there is absolute possibility of co-occurrences in such phenomenon in the constructions of Meetei proverbial sentences.

Before we reveal the features of Meetei proverbs in detailed the following features of Efik proverbs can discuss as an example.

1 (a) Éyén ké é- brě yé èkà ntè í- dí- túá -há túá

[Mensah, 2010]

Child AUX 3SG- play PREP mother like 3SG-FUT-cry-NEG EMP

"The child is playing with his mother as if he will not cry".

Sé ákámbá ówò é- tié dé tié ó- kút, éyénọwọn í- dá -há dá í- kút

[Mensah, 2010] 
What big person 3SG-sit ES EMP 3SG-see child 3SG-stand-NEG-EMP 3SG-see

"The thing an elder sits down to see cannot be seen by a child who is standing".

The constituents $i$ - dí- túá -há túá "He will not cry (cry emphasized)" in 1(a) and é- tié -dé tié "He sits down (sit emphasized)" as well as $\dot{i}$ - dá - há dá "He cannot stand (stand emphasized)" in 1(b) found highly agglutinative. In these structures, each morpheme corresponds to a single lexical meaning or grammatical function. In 1(a) the $i$ - dí túa há túá has the features of the third person singular marker, future tense marker, root verb, negation marker and emphasis.

Thus, theoretically morphological and semantical features are considered as the key features in the study of Meetei proverbial sentences in the manner of how a verbal inflectional marker co-occurred in different morphemes.

\subsection{Analysis of Proverbs in Meeteilon (Manipuri)}

Umoh (2007) categorised proverbs in two types such as Proverb-riddle and Conventional proverb. Proverb-riddle has two parts of saying which combines the attribute of both the riddle and proverb. Salzmann (1998) argues that proverbriddles are:

“...puzzling questions based on some unexpected connections with a solution that is to be guessed. They serve as a good example of oral folklore that is constantly renewing itself. They are favourite form of entertainments between teams of individuals, both young and adults."

This form of genre is usually employed in riddle and playing games like mind game, word game in the test of intelligence, capability, cleverness, etc. As for conventional proverbs, proverbs can be categorised into various classes based on the profession, things, situations, way of living, belief systems, experiences, foot-habits, etc. Brunvand (1978) also says that there are proverbs on beliefs, proverbs based on weather signs, medical lore, business, folk law, proverbs deriving from historical events or slogans or household or form of tasks, etc.

With reference to above theories, Meetei Proverbs can be categorized into thirteen subclasses based on their professions, traits, things \& household utensils, situations, way of living, folk belief systems, societal belief systems, medical lore, teaching, learning and experiences, foot-habits, form of tasks, kingdom or societal rule and regulations, weather signs, natures, etc. For effectively interpreting the meaning of these thirteen subclasses, Leech's (1974) seven types of meaning can be the most effective instruments in categorizing the meanings in the study of these Meetei proverbs.

\subsection{Features of Meetei Proverbs}

Meetei proverbs have the features of stylistics with association of strong morphological affixations such as derivational as well as inflectional in the lexical constructions. In little stylistics, rarely Meetei proverbs and riddles were mixing along with folkloristic telling. As a phenomenon, Meetei proverbs and riddles made tells tricky and pithy conclusion which is asking and puzzling something valuable for the future and wisdom of the experiences in life. Only the wise or clever man could understand the actual theme that has been concealing behind tells as sayings and riddles. Hence, in the monarchical days of the history of Manipur, only the witty and clever man adorned the royal court of emperor. So, the riddle and proverbial sayings were the only means to intrigue royal palace. For instance, Meetei priests, court jesters, spiritual orators and others those who were supported to adorn the royal court used proverbs such as in example (3). The other types of Meeteilon proverbs are using based on the above-mentioned thirteen subclasses of proverbs. They are as follows:

2. Proverbs that related to/based on King and Court Jesters:

$\begin{array}{lllllllll}\text { wasə-su } & \text { ca-bə } & \text { lallup-su } & \text { ka -ba } & \text { nint }{ }^{\text {həw }} & \text { mənai } & \text { cao-bə-rə } & \text { pik-pə-rə } & \text { yen-u. } \\ \text { Stick -also } & \text { eat-NMZ } & \text { compensation-also } & \text { give-NMZ } & \text { King } & \text { servant } & \text { big-NMZ-INT } & \text { small-NMZ-INT } & \text { look-ASP. } \\ \text { Stick also } & \text { Eat } & \text { Compensation-also } & \text { giving } & \text { King of } & \text { servant } & \text { big? } & \text { small? } & \text { look. }\end{array}$

Theory: Contextual

Types: Connotative/Collocation

Literally: "After giving compensation along with punishment people acknowledge the power of royal servant".

Social Meaning: It refers that "This proverb used to show that the power and cleverness tricks of the court jesters against the convict." For a small guilty someone has to pay compensation along with punishment of bitterly beating him, then he came to know and realized that how a royal court jester use their/his power and justice. It taught us that instead of facing a big suffer in such a way, it is better to apologize in time to the authority by telling the truth and real causes, rather than showing smartness.

3. Proverbs that related to/based on Married and Marital Life

$\begin{array}{llllll}\text { topan-ca -bə } & \text { kum-də } & \text { sendan } & \text { mət }^{\mathrm{t}_{\mathrm{i}}} & \text { əna-ni } & \mathrm{k}^{\mathrm{h}} \mathrm{ul} \text {-li. } \\ \text { Separate-eat-NOM } & \text { weather-DET. } & \text { sparrow } & \text { dung } & \text { 1paisa -COP } & \text { pick-up-ROG. } \\ \text { To be a nuclear family } & \text { at time } & \text { sparrow } & \text { stool } & \text { is one paisa } & \text { picking up. }\end{array}$

Theory: Referential

Types: Collocative/Reflective/Connotative 
Literally: "To set-up a nuclear family a married couple even pick-up stools of sparrow like a Coin of Anaa (One Coin of Indian Currency)."

Social Meaning: It refers that "When a husband and wife set up a new house every small particle or thing is required and even more valuable for house whole use." They tried to keep whatever they got, they did not even think that what they acquired is useful or not. They just kept collecting whatever they see; sometimes they even collected/picked-up stools of a sparrow by thinking that may be useful like a coin of paisa (Indian currency) for them. It taught us that when a new couple set up a new house they became scrooge/churl by nature in order to set up the family.

4. (a) Proverbs that related to/based on Food and Meals

$\begin{array}{lllll}\text { kwa } & \text { mətəp } & \text { əmə -nə } & \text { cin } & \text { pəy. } \\ \text { Paan } & \text { Piece } & \text { one -INST. } & \text { Mouth } & \text { lean. } \\ \text { Paan } & \text { piece } & \text { by one } & \text { the mouth } & \text { delicious. }\end{array}$

Theory: Ideational

Types: Connotative/Affective

Literally: "Even a piece of Paan (Betel Leaves \& Areca nut) serves the mouth more delicious."

Social Meaning: It refers that "Even an amount of the thing is very little, if it comes/uses at time, it works wonder." When you tried to build up a relationship with someone we try to invest a huge energy, money and other sources. Though you are invested everything, sometime it is very difficult to build up the relationship or to make him in your favour. Instead, if we simply gift him a piece of Paan at the right time (the time when he is in good mood), after he had it he willingly ready to do any kind of favour without any cost. It taught us that when you asked favour to someone find for his favourite thing and give him it at the right time.

5. (b) Proverbs that related to/based on Food and Meals

$\begin{array}{llll}\text { ə’aobə -gi } & \text { p }^{\text {həwsu -nə }} & \text { čəra } & \text { non }-k^{\text {h}} \text { ən }- \text { nəy. } \\ \text { Lunatic -P.PRO. } & \text { husk/pound -INST. } & \text { Meal } & \text { day-save -REC. } \\ \text { Of lunatic } & \text { to pound of } & \text { a meal } & \text { used for a day. }\end{array}$

Theory: Contextual

Types: Referential/Contextual

Literally: "A lunatic saves a day from hunger to remove the husks of rice."

Social Meaning: It refers that "A lunatic is even useful to remove the husks of rice". Though he is a lunatic, if we keep him working; the works he had done will always have some good results. That is how if we operate a lunatic man in removing husks of rice, such act of him may even save a day from hunger. It means the good result coming from an unexpected person like lunatic (man) is also fruitful. It taught us that we should not underestimate to anything everything has its own purposes. Instead of underestimating, we should try to find the real purpose.

6. Proverbs that related to/based on King and Queens

$\begin{array}{lll}\text { nint }^{\mathrm{h}} \text { əw -do -su } & \text { maital } & \text { wat -li. } \\ \text { King -DET. -also } & \text { charcoal } & \text { shortage -PP. } \\ \text { Even the king also } & \text { charcoal } & \text { shortage of. }\end{array}$

Theory: Contextual/Ideational

Types: Collocative/Connotative

Literally: "Even the king's charcoal is limited."

Social Meaning: It refers that "Limitation is for everyone." It used to say that if a person lost his ego to live his life we used to say this proverb by motivating his ego to live life longer with full of courage and zeal, as he should work hard to live his life like other people. Limitation is for everyone, and no one is fully wealthy even the king sometime has no charcoal. In other case, if a person shows his proudness and wealth as he is the only one who is wealthy. We used to say this proverb to make him realize his weakness that he is not as wealthy as king. He is also nothing with comparison to king's worth, power, properties and wealth. Nevertheless, even such king sometime has no charcoal in his forth.

7. (a) Proverbs that related to/based on Profession and Occupation

$\begin{array}{lllll}\text { nəha -nə } & \text { maibə } & \text { sa -rəgə } & \text { mə๊ } & \mathrm{t}^{\mathrm{h} ə l} \text {-li. } \\ \text { Young -NOM. } & \text { Traditional physician } & \text { make-after } & \text { graves } & \text { full -PP. } \\ \text { By young man } & \text { traditional physician } & \text { after becoming } & \text { of graves } & \text { is full }\end{array}$

Theory: Contextual/Referential

Types: Denotative 
Literally: "A callow physician makes full of graves."

Social Meaning: It refers that "If a young and an inexperienced person acts like an expert, there is always risk." Traditionally, people believe that an experienced physician who becomes old age and is working on the same profession since many years can treat a chronic patient well. Whereas, a callow physician cannot treat as the old experienced physician treated the chronic patient. If the callow physician treats continuously, there is possibly risk. His act may even cause the patient's life. If he continuously treats many patients the number of risks will also increase, that is how the possibility of increasing the number of dead body will also increase. Therefore, there will be lot of graves. It taught us that an inexpert person acts like an expert there will be risk.

(b) Proverbs that related to/based on Profession and Occupation

$\begin{array}{llll}\sin -\mathrm{p}^{\mathrm{h}} \text { əm } & \text { yam -ləgə } & \text { məhəy } & \text { ca -de. } \\ \text { Profession } & \text { many -after } & \text { fruit } & \text { eat-NEG.SAM. } \\ \text { Profession } & \text { of many } & \text { Fruitful } & \text { not eaten }\end{array}$

Theory: Realist/Ideational

Types: Denotative/Collocative

Literally: "If a person has many occupations he is became unfruitful."

Social Meaning: It refers that "People pay a price for being always on the move, in that they have no roots in a specific profession, so they became unfruitful/ unsuccessful." When a person frequently changes his professions he would have lot of basic knowledge or skills in many fields, but he cannot have the skills that become a master in one specific field. That is why people will not hire him for high paid/ high profile job as a master. At last, his engagement will become unfruitful.

8. Proverbs that related to/based on Medical

$\begin{array}{lllll}\text { cak } & \text { cək }{ }^{\mathrm{h}} \text { om } & \text { əmə -nə } & \text { puk-cep } & \text { na-i. } \\ \text { Rice } & \text { morsel } & \text { one -NOM. } & \text { Stomach-abdomen side } & \text { pain-ASP. } \\ \text { Rice } & \text { morsel } & \text { by one } & \text { side of the stomach } & \text { pain. }\end{array}$

Theory: Contextual

Types: Affective/Connotative

Literally: "If stomach is full even a morsel of rice can make stomach ache."

Social Meaning: It refers that "Doing something more than necessary will harm us." People generally realized when they faced some unwanted consequences with them. Before the consequences comes to them they just lore for the things that lies just in front of them, instead of thinking/realizing it as over excess. If the thing is even very small or little it makes the effect unexpectedly harm to us. It taught us that avoid having over excess, take only that you required otherwise it would harm you.

9. (a) Proverbs that related to/based on Weather and Monsoon

$\begin{array}{lllll}\text { poinu -də -di } & \text { uci -dəp }{ }^{\mathrm{h}} \text { əo } & \text { nupi } & \text { təret } & \text { lol -li. } \\ \text { December -DET. -to. } & \text { rat -at least } & \text { wife } & \text { seven } & \text { step marry -PROG.ASP. } \\ \text { At harvesting month } & \text { even a rat } & \text { wife } & \text { seven } & \text { step marrying. }\end{array}$

Theory: Contextual

Types: Stylistic/Thematic

Literally: "In the month of harvesting, even a rat has seven wives."

Social Meaning: Everyone has enough grains in the time of harvesting so that they do whatever they like without any care. In this season, a rat found enough grains to have so they even have the guts to get step marrying. It refers that in the season of harvesting every man has enough grains so every man wants to get full of entertainment. As they had, enough grains they started having enough confidence to live their lives, sometime they even have the guts to get step marrying. It taught us that everyone is happy without any care in harvesting season.

(b) Proverbs that related to/based on Weather and Monsoon

\begin{tabular}{|c|c|c|}
\hline tənaip ${ }^{h} ə d r ə b ə d i$ & həџоi -dəp ${ }^{h} ә 0$ & kum -dəm-mi. \\
\hline at critical time & frog -least & weather -fix-ASP. \\
\hline it the critical situation & by frog & predict the weather \\
\hline
\end{tabular}

Theory: Ideational

Types: Denotative/Stylistic

Literally: "At the critical situation, a frog predicts the weather." 
Social Meaning: It refers that "If no one can find a way people generally started perceiving another way from that they could merely understand, so that people learn the prediction of weather even from frogs." When people cannot predict weather of the day, they tried to find from other means to get it such as they tried to get some possible ideas from how a frog is moving in the riverbank. It taught us that if people do not find means they tried to gauge through near sources.

10. (a) Proverbs that related to/based on Animal, Birds and Fishes

$\begin{array}{lll}\text { kəi-nə } & \text { məyek } & \text { majbə -rə? } \\ \text { Tiger-NMZ } & \text { stripes } & \text { lost -INT. } \\ \text { Of tiger } & \text { stripes } & \text { lost from the fur? }\end{array}$

Theory: Referential

Types: Connotative

Literally: "The tiger cannot change its stripes."

Social Meaning: It refers that "Every person has his own identification that he himself cannot change." Every tiger has stripes as its identity that cannot change its colours. Only the tiger has these stripes no other animal does have, these stripes are its identity. It taught us that if a person wants to show his identity as different from the actual one, he somehow shows his own identity.

(b) Proverbs that related to/based on Animal, Birds and Fishes

$\begin{array}{lll}\text { kəinə } & \text { tokpə } & \text { pokpə -ra? } \\ \text { Tiger } & \text { fitchew /polecat } & \text { birth -INT.? } \\ \text { By tiger } & \text { fitchew/polecat } & \text { gives birth? }\end{array}$

Theory: Ideational

Types: Connotative/Referential

Literally: "No tiger gives birth to a fitchew kitten."

Social Meaning: It refers that "Tiger gives birth to tiger cubs like fitchew gives birth to fitchew kittens so that the father gives birth to child who behaves in the same ways, and has same talents or defects." Generally, when a child gives extraordinarily good result/performance his father used to say to quote that as he has such talent his son/daughter also has it. In other case, when a child gives very worse performance/result or commits worse incidence, other people used to say to quote that as his father or ancestor had also committed as it, he is also doing the same.

(c) Proverbs that related to/based on Animal, Birds and Fishes

$\begin{array}{llllll}\text { lok } & \text { əmə -də } & \text { kəi } & \text { əni } & \text { kun -bə } & \text { ya -de. } \\ \text { Canyon } & \text { one -LOC. } & \text { tiger } & \text { two } & \text { sit-down -INF. } & \text { agree-NEG. } \\ \text { Canyon } & \text { to one } & \text { tiger } & \text { two } & \text { settle } & \text { not happen. }\end{array}$

Theory: Contextual/Ideational

Types: Stylistics

Literally: "No two tiger can settle in the same den."

Social Meaning: It refers that "Two men of a same position cannot work together. If they work together they used to quarrel each other." Generally, one tiger settle in one canyon, another tiger settle in another canyon, that is how two persons of the same rank/position settle in different places. If they settle in a place together, the chances of happening misunderstanding are high due to their egos and personality.

11. Proverbs that related to/based on Human Physical

$\begin{array}{lll}\text { lukokpə -də } & \text { len } & \text { ta-i. } \\ \text { Bald -to } & \text { hail } & \text { drop-SAM. } \\ \text { To bald of (head) } & \text { hail } & \text { dropping. }\end{array}$

Theory: Contextual

Types: Thematic/Denotative

Literally: "Hails drop on the baldhead."

Manipuri Meaning: It refers that "The situations that happened bad incidence after incidence." When a person suffered from a major bad incidence, he needs time to recover it fully. Before he recovered it fully happen another incidence with him that is more dangerous than the previous incidence. It taught us that if a person faced such situations in his faith, it is very hard to recover in short time. If something happened with you as it, you need support from other.

12. Proverbs that related to/based on Trees and Plants

uhəi yam -no pan -bə $u$ moru luk $-\mathrm{i}$




\begin{tabular}{|c|c|c|c|c|c|}
\hline Fruit & many -Nom. & bear-INF. & tree & head & down -assure-SAM. \\
\hline Fruit & of many & bearing & tree & head & is bending. \\
\hline
\end{tabular}

Theory: Referential/Stimulus Response

Types: Thematic/Connotative

Literally: "Fruit bearing trees are humble."

Social Meaning: It refers that "Those persons who are learned and having good knowledge are always humble." It used to say when a person knows few things and showing his knowledge as better than everyone does. People advised him not to do as it, the person who knows very much and learned lots of thing always keep mum and humble. You are trying to show because you want to act like an expert, but you are not known as an expert knows.

13. Proverbs that related to/based on Father and Mother

$\begin{array}{llll}\text { mapa -gi } & \text { məca } & \text { u -gi } & \text { uhəi. } \\ \text { Father -of } & \text { son } & \text { tree }- \text { of } & \text { fruit-SAM. } \\ \text { Father's } & \text { son } & \text { tree's } & \text { fruit. }\end{array}$

Theory: Contextual

Types: Collocation

Literally: "Like father like son and like tree like fruit."

Social Meaning: It refers that "Different generations of a family behave in the same way or have the same talents or defects." The good father gives birth for a good son and good tree gives good fruit. Thus, the son of a father acts or behaves according to his father and has the same talents and the same will as his father does.

14. Proverbs that related to/based on Societal Protocol

$\begin{array}{lllll}\text { iroi } & \text { wai-nə -bə } & \text { mətəi-mənəo } & \mathrm{k}^{\mathrm{h}} \text { ət-nə -bə } & \mathrm{k}^{\mathrm{h}} \mathrm{am} \text {-gənu. } \\ \text { Buffalo } & \text { fight-INT -INF. } & \text { husband-wife } & \text { fight-INT-NMZ } & \text { stop-NEG. } \\ \text { Buffalo } & \text { fighting of } & \text { husband and wife } & \text { fighting of } & \text { don't stop. }\end{array}$

Theory: Stimulus/Contextual

Types: Affective/Connotative

Literally: "Do not stop while married couple screaming and two buffaloes fighting each other."

Social Meaning: It refers that screaming between husband and wife in married life is common, and fighting between two buffaloes is also common in a herd. Soon after the fight is over the couple or buffaloes would be together, they will forget everything that happened between them. It taught us that we should not involve in stopping the fight of married couple or two buffaloes. If we forward to stop them by force for the moment, later on, they would forget everything that happen between them, but will not forgive other for their acts. It may effects in our relationship (or harm us in case of buffaloes) unnecessarily.

15. Proverbs that related to/based on Son, Daughter, and Relatives

$\begin{array}{lll}\text { məw } & \text { ənəw -bi } & \text { mərəm-ok-i. } \\ \text { Woman } & \text { new -FEM. } & \text { obedient. } \\ \text { Daughter-in-law } & \text { new } & \text { is obedient }\end{array}$

Theory: Stimulus Response

Types: Denotative/Stylistics

Literally: "A newly married woman is always obedient."

Social Meaning: It refers that "When a maiden become woman at the beginning of their married life they are very obedient, sincere and hard working in order to show people and their inlaws that she is good, obedient and hardworking. Some days later, she started showing her true nature, habits and behaviour. It taught us that every newly married woman is obedient, but it does not mean that she is good at all.

16. (a) Proverbs that related to/based on Vessels, Utensils and Pots

$\begin{array}{llll}\mathrm{t}^{\mathrm{h}} \text { əwban-dop } & \operatorname{cəp}^{\mathrm{h}} \mathrm{u}-\mathrm{bu} & \text { kai -nə -bə } & \text { yəy -bə-rə? } \\ \text { Thoubaal-from } & \text { pot -DEF. } & \text { Break -NOM.-INF. } & \text { bit -INT. } \\ \text { Of Thoubal } & \text { that pot } & \text { for breaking } & \text { is biting? }\end{array}$

Theory: Contextual/Referential

Types: Reflective/Collocative

Literally: "Is Thoubaldong pots' beaten to break?" 
Social Meaning: It refers that "Beating or scolding to their child is not because of hatred, it is for making their child perfect." In Meetei society, there is a place called Thoubal (Thoubal District, in Imphal), is popularly known as the place for making/producing fine pottery products. In Thoubal, every potter beats or hits the pots when they made those pots. They bit/hit the pots only because to get the shapes in which they like. They are not biting/hitting the pots to break it they just hit the pots to get the good shapes. As the potters beats the pots, parents/guardians beats /hits their child to become a good man in future. Generally, a father/mother feels angry and mind when someone bits his or her child. However, it advised us that do not mind when guardians or elders beat your child they bit your child just to teach him something.

(b) Proverbs that related to/based on Vessels, Utensils and Pots

$\begin{array}{llll}\text { cəp }^{h} \mathrm{u} & \text { uyan }- \text { dəp } \mathrm{p}^{\mathrm{h}} \text { ao } & \text { nonp } \mathrm{p}^{\mathrm{h}} \text { adok } & \mathrm{k}^{\mathrm{h}} \text { et-nəy. } \\ \text { Pot } & \text { cauldron -even } & \text { Sometimes } & \text { touch-usual } \\ \text { Pot } & \text { even the cauldron } & \text { Sometimes } & \text { Touching }\end{array}$

Theory: Contextual/Referential

Types: Stylistic/Connotative

Literally: "Pot and cauldron even crunch each other."

Social Meaning: It refers that "Sometimes married couple screaming to each other, but screaming or fighting in such a way is common to all married couple. So such screaming and quarrelling is common in a couple." When we cook something in the kitchen pot and cauldron are touching or crunching to each other while moving from one place to another. But, it does not spoil the food. However, they touch each other and having the sound of crunching, the cook used to make food without any harm. Therefore, such incidences are common to all the cooks.

17. Proverbs that related to/based on Festival and Occasion

$\begin{array}{llll}\text { moiran } & \text { hərao -rinəi -də } & \text { kum } & \text { kan -bə. } \\ \text { Moirang } & \text { happy -in the time-ASP } & \text { season } & \text { lost -INF. } \\ \text { Moirang } & \text { while celebrating } & \text { season } & \text { is lost }\end{array}$

Theory: Contextual

Types: Connotative/Thematic

Literally: "While celebrating the deity (of Moirang) throughout months surpass the season".

Social Meaning: It refers that "Enjoying the present moments of the festival of Moirang deity without realizing the consequences makes their future hardship." The Moirang deity is a deity called "Lord Thangjing" resided in the place of Moirang, in Manipur. In short, the celebration is known as Thangjing Haraoba (Deity Celebration of Thangjing/Moirang Festival), which is also regarded as one of the great holy festival in Manipur and celebrated the deity festival throughout a season. While people of Moirang celebrating this deity festival and enjoying throughout a season, the season surpassed without any cultivations and crops. When the festival is over, they become realized that the season has already surpassed.

From the above proverbs, the morphosemantic feature of verbs may examine from the functions of lexical items that attribute different meanings in the Meetei proverbs. For this, the formation of words into morphemes and possibilities of suffixes, prefixes, and infixes to those morphemes have necessarily studied as following.

\subsection{Morphological Features}

The most frequently used verbal inflectional markers in Meetei proverbial sentences are “-li”, “-u”, “-nəy”, “-mi”, “rə" and "i". They exist as morphological or semantic inflectional markers in most of the constructions. Among these markers, the inflectional marker "-li" is used more frequently in various proverbial sentences other than "-u", "-nəy", “-mi”, "-rə", "i" and "gənu".

The marker "-li" in the verbs wat -li "is shortaged" in (5) and $t^{\text {h }} \partial \mathrm{l}$-li "is fulled" in (7a) are present participle (PP) and $k^{h} \mathrm{ul}$-li "picking-up" in (3) and lol -li "is step-marrying" in (9a) are present progressive (P.PROG.) tense. These verbs show that the suffix - $\mathrm{l} i$ is capricious on the basis of the selection to which it attaches and in the meaning of the words which result from the suffixing it. Hence, the functions of suffix "-li" used in all the contexts of the above Meetei proverbs are inflectional and agglutinative by meanings. Therefore, the functional features of these different inflectional morphemes "-li" can be seen from the following formations.

a) Formation:

\begin{tabular}{|c|c|c|c|c|c|}
\hline Suffixes & Stem & Function & Attach to & Output & Meaning \\
\hline -li (in 6) & V & $\mathrm{PP}$ & {$\left[\left\{w^{\prime} t_{v}\right\} l i{ }_{P P}\right]$} & [wa'tli] v.PP & is shortaged \\
\hline -li (in 7a) & V & PP & {$\left[\left\{\mathrm{t}^{\mathrm{h}} \partial_{\mathrm{V}}\right\} \mathrm{li}_{\mathrm{PP}}\right]$} & {$\left[\mathrm{t}^{\mathrm{h}} \partial \mathrm{li}\right]_{\text {V.PP }}$} & is fulled \\
\hline -li (in 4) & $\mathrm{V}$ & P.PROG. & {$\left[\left\{\mathbf{k}^{\mathrm{h}} \mathrm{ul} \mathrm{v}\right\} \mathbf{l i}_{\text {P.PROG. }}\right]$} & [k $\left.\mathrm{k}^{\mathrm{h}} \mathrm{ulli}\right]_{\text {V. P.PROG. }}$ & picking-up \\
\hline -li (in 9a) & V & .PROG. & {$\left[\left\{\mathrm{lol}_{\mathrm{v}}\right\} \mathrm{li}_{\text {P.PROG. }}\right]$} & [lolli $]_{\text {V. P.PROG. }}$ & is having step-wife \\
\hline
\end{tabular}


From the above formation, we found that inflectional suffix "-li" is always bound with the root morphemes wat, $\mathrm{t}^{\mathrm{h}} \mathrm{\rho l}, \mathrm{k}^{\mathrm{h}} \mathrm{ul}$, and lol. In other formations the suffix "-li" is always attached to other verbal roots and bounding to root morpheme. It can't affix to nouns, pronouns or other subjective verbs in Meetei proverbs. Katamba (1994:77) has asserted the selection of affixes that co-occurred with a particular base. It may depend on that base which is being a member of a particular paradigm, i.e. a purely morphological sub-class. He says the morphemes belonging to different paradigms take different affixes and frequently occurred in the case of inflectional morphology.

The inflectional suffix marker "-li" in (6) and (7a) functions as Present Participle (PP) markers with an aspectual meaning to the root or main verb, whereas in (4), and (9a) "-li" functioned as Present Progressive (P.PROG) markers with an aspectual meaning to the root or verb. As we have seen, depending on which paradigm a verb belongs to, the above verbs co-occur with different allomorphs of inflectional suffix morphemes. This existence of paradigm is very important for understanding the nature of allomorphs in the formation of Meetei Proverbial Sentences.

The other inflectional marker "-u" in the verb yen-u "see" is aspectual and it makes verbal imperative meaning in (3). The marker "-nəy" in the verb nop - $k^{h}$ on -nəy "used for a day" in (5b) and $k^{h} e t-n \partial y$ "usually touching or fighting" in (16b) it simply shows the action happened usually or in usual nature. The marker "-mi" in the verb kum-dəm-mi "predict the weather" in (9b) is an aspectual markers. The marker "i" in the verbs ta-i "dropping" in (11), in the verb luk $-i$ "is bending" in (12), and in the verb morəm-ok-i "obedient or humble" in (15) are simple aspectual markers that is occurring as non-hypothetical meaning. The marker "-rə" in the verb mapbə -rə "lost from the fur" in (10a), in the verb pokpə -ra "give birth" in (10b) and in the verb yəy -bə-rə "is biting" in (16a) are interrogative markers. The marker "gənu" in the verb $\mathrm{k}^{\mathrm{h}} \mathrm{am}-\mathrm{g} \mathrm{n}$ "don't stop" in (14), de in the verb ya-de "not agreed" in (10c), and "de" in the verb ca-de "not eaten" in (7b) are negative inflection markers.

In (6) and (7a) the present participle "-li" which is aspectual by meaning shows usual actions other than indicating as tense marker of the action in the sentence. It indicates the action occurred as usual or as general. It may indicate the cause or result of the action that will be same to everyone as universal so it becomes general or common for all. Whereas, in (4), (7b) and (9a) the marker "-li" indicates time that the actions have been taken place or showing the time of the action that have been associating with the subject.

\subsection{Semantic Features}

The semantic consideration of the following verbs wát-li, $t^{\mathrm{h}} \mathrm{\partial l}-\mathrm{li}, \mathrm{k}^{\mathrm{h}} \mathrm{ul}-\mathrm{li}$, ta'l-li and lol-li have various word formation processes. For example, instead of affixing the lexical item "-li" as suffix to the verbs if we affix it as prefix or infix to the same verbs there is possibilities of semantic consideration. For instance, the lexical item "-li" is attached to the verb "khul", it forms "likhul", has more positive meaning as 'origin of something'. In other case, if we affix any other morphemes such as "-de" or "-te" as negation or "kə/gə-ni" as future to the same morpheme, it also has one semantic formation. However, the targeted semantic meaning of a proverbial sentence is lost due to more negative morpheme is used in to the contexts. For instance, the morpheme 'de' attached to the verb wát as suffix will form wa't-te, as Present Participle Tense (PPT) that means 'is not shortaged' has no negative meaning in the proverbs. Hence, we can say that in Meetei proverbial sentences there is a semantic restriction to the application of morphological rules, while the same morph, allomorph or morpheme affixing to the verbs. Such semantic restrictions of the word formation pattern can be examined from the following features:

b) Formation:

$\begin{array}{ccc}\text { Root Verb } & \text { Phonological Shifting } & \text { Negative Suffixes } \\ \text { wát } & \text { NIL } & \text {-te } \\ t^{h} \text { əl } & \text { from '-l' to ' } n \text { ' } & \text {-de } \\ \mathrm{k}^{\mathrm{h}} \mathrm{ul} & \text { from '-l' to ' } \mathrm{n} \text { ' } & \text {-de } \\ \text { tal } & \text { from '-l' to ' } \mathrm{n} \text { ' } & \text {-de } \\ \text { lol } & \text { from '-l' to ' } \mathrm{n} \text { ' } & \text {-de }\end{array}$

Semantic Restriction
wa't-te
$\mathrm{t}^{\mathrm{h}}$ on-de
$\mathrm{k}^{\mathrm{h}}$ un-de
ta'n-de
lon-de

Meaning
not enough
not full
not pick-up
not earning
not having step-wife

As we have seen above, the formation of negative morpheme "-de" or "-te" make meaning but it is semantically restricted for suffixing to any one of these verbs. If once we suffix it to the root verbs, the targeted meaning of the proverbial sentence is lost. On the other formations, if we affix the P.PROG. suffix "-li" to the beginning as prefix of the root verb such as "liwat, lithol, litál and lilol has no meaning but only in a case of the verb "lik"ul" has meaning which is distinctive from the actual meaning and it referred as 'origin of something or somebody'. As the other languages have the processes of placing morphemes as prefix, infix and suffix in the formation of negative morphemes or words, in the case of Meeteilon (Manipuri) word formation process, there is a strict restriction to the application of semantic rules. Therefore, we consider that the application of the word formation process in Meetei proverbial sentences is strictly bound by semantic rules, even though, the morphological possibilities are there to form few formations of words.

\subsection{Other Considerable Features}

From the typological linguistic viewpoints, the Meetei proverbs are rhetorical, epistemological, didactic and philosophical. Most of the Meetei proverbs reveal that Meetei (Manipuri) are mostly tellers, artists, philosophers and thinkers whose intellectual, cultural and mythological eruditions manifest in reality. They simply believe on what they have seen and experienced. Most of their cultural ethoses are referential based on their experienced in livelihood from generation to generation. Majority of Meetei proverbs are didactic and philosophical. For instance, the proverbs in (3), (5b), (7a), (7b), (8), (10a), (10b, (10c) (12), (15), (16a), and (16b) are didactics and in (2), (5a), (6), (9a), (9b), (10c), (11), (13), and (14) are philosophical forms. One interesting finding is that Meetei constructed didactic and 
philosophical proverbs through most of their rhetorical and epistemological experiences. For instance, the proverbs in (3), (7a), (9a), (9b), and (17) are from Epistemological references and in (5b), (7a), and (7b) are from rhetorical references. It clearly indicates that majority of their knowledge of the constructions of proverbial forms are closely related to their society, philosophy and believe systems. From the various contexts of these proverbs, this study reveals that in early age it seems that some persons were assigned professionally by the king to construct profound ideas, thoughts and belief systems with reference to various traits and fields based on their contextual and philosophical thought processes. At the same time, they acknowledged new innovative ideas and experiences from their acts of failures or deeds, and used it to structuralize the society and the ruling.

In other cases, the literary genres of Meetei proverbial sentences are poetical, rhetorical and philosophical. It is crafted with a diverse range of figures of speech. Many characters are metonymies i.e. 'bald head' refers 'a person who is suffering from a dangerous situation' in (11), and 'Thoubaldong pots' refers 'the babies or children who are shaping their behaviour by their parents' in (16a), etc. It also referred the characters like intelligence or fool, sluggard or diligence, righteous or wicked, etc. The figurative features of similes and metaphors are also found in various Meetei proverbs such as the similes 'Like father like son' in (13) and 'Tiger gives birth to tiger cubs like fitchew gives birth to fitchew kittens' in (10b), etc. The hyperbole is also a characteristic that is very common in the world of proverbs. Its overstatement and exaggerated nature of meanings help the Meetei proverbs to emphasis on the issue that is being encapsulated. For instance, the proverbs 'A lunatic (man) saves a day from hunger to remove the husks of rice' in (5b), 'A callow physician makes full of graves' in (7a), 'If stomach is full even a morsel of rice make stomach ache' in (8), 'Do not stop while married couple screaming and two buffaloes fighting each other' in (14), and 'While celebrating the deity (of Moirang) throughout months surpass the season' in (17) are hyperbolic features which are in the forms of figures of speech in Meetei proverbs.

\section{Conclusion}

Meetei proverbs represent the significance of using verbal language. Proverbs used in Manipuri is highly agglutinative by nature, it reflects to the meaning of its interpretations. The verbal features of the proverbs have complex grammatical functions according to its different semantic and morphological levels. For instance, the formation of words into its morphemes and possibilities of affixes to that morpheme are contextual, ideational, referential, and realist. On the other hand, the function and the features of lexicon marks high level of structuralism bridged to pragmatics, stylistics, semantic and morphology. So as the levels of agreement between verbs and other lexical items are complex in particular aspects of meaning. However, this is something that I could have find and claim that Meetei proverbs sustain a strong literary and linguistics bond.

\section{References}

Abrahams, R.D. (1972). Proverbs and Proverbial Eexpressions. In: R.M. Dorson, Ed. Folklore and Folklife, Chicago: University of Chicago Press, pp.117-127.

Baruah, M. (2008). The Co-Wife and Step-Mother Motifs in Folklore: A Case Study of Some Assamese Proverbs. Indian Folklife: Assamese Folklore, 31.

Beerjita Devi, L. (2007). Manipuri Paorou Neinaba. Lamyanba Printers, Imphal: Konung Mamang.

Brunvand, J. H. (1978). The Study of American Folklore: An Introduction. W.W. Norton and Co. Inc., New York, 1.

Cram, D. (1983). The Linguistic Status of the Proverb. In: Wise Words: Essays on the Proverb, (Ed.) Wolfgang Mieder, pp.73-98.

Croft, W. (2001). Radical Construction Grammar: Syntactic Theory in Typological Perspective. Oxford: Oxford University Press.

Goddard, D. (1998). Semantic Analysis. Oxford: Oxford University Press.

Goodwin, P.D. and Wenzel, J. W. (1979). Proverbs and Practical Reasoning: A Study in Socio-Logic. The Quarterly Journal of Speech, pp. 289-302.

Lawal, R. A. (1992b). English Language and a Patriarchal Worldview. Savana, 13(2), 74-79.

Lawal, A. (1997). A Pragmatic Study of Selected Pairs of Yoruba proverbs. Journal of Pragmatics, 27, pp.635-652.

Katamba, F. (1994). Morphology. Mackmillan, London: Hamsphire.

Maria, L. (1996). Definitions of Folklore. Journal of Folklore Research, 33(3), 255-264.

McKoon, Gail. et. al. (1993). Morphosyntatic and Pragmatic Factors Affecting the Accessibility of Discourse Entities. Journal of Memory and Language, 32, 56-75.

Mieder, W. (2004). Proverbs: A Handbook. Greenwood Press, Wesport: Post Road West.

Mensah, E. O. (2010). A Morphosyntatic Analysis of Efik Proverbs. An Ambilingual Interdisciplinary Journal, Glossa, 5(2), 250-281.

Mwihaki, A. (2004). Meaning as Use: A Functional View of Semantics and Pragmatics. Swahili Forum, 11, pp.127139.

Norrick, N. R. (1985). How Proverbs Mean: Semantic Studies in English Proverbs. New York: Amsterdam. 
Saussure, F. D. (1968). Cours De Linguistique Générale. (ed.) Critique Par Rudolf Engler, Tome 1. Wiesbaden: Harrassowitz.

Salzmann, Z. (1998). Language, Culture and Society: An Introduction to Linguistic Anthropology. Oxford: Westview Press.

Spencer, A. (1991). Morphological Theory. Oxford: Basil Blackwell.

Umo, S. (2007). Ibibio Proverbs as a Tool for Language Pedagogy. Presented at: Valedictory Symposium in Honour of Professor Okon Essien. 